\title{
Hubungan antara Tahap Ganjaran dan Komitmen Organisasi dengan Penglibatan Pekerja sebagai Pemboleh Ubah Pengantara
}

(Relationship between Reward Level and Organizational Commitment with Employee Engagement as Mediating Variable)

\author{
Nur Syafiqah Abdul Samad, Azman Ismail, Khairul Azman Aziz
}

\section{ABSTRAK}

Dalam perspektif perhubungan pekerjaan, tahap ganjaran seringkali diiktiraf sebagai instrumen yang sangat penting untuk menarik, memotivasi dan mengekalkan pekerja yang kompeten bagi mencapai dan mengekalkan matlamat dan strategi organisasi-organisasi yang berprestasi dan berdaya saing tinggi. Kajian terbaharu mendapati bahawa tahap ganjaran yang ditentukan setimpal dengan kriteria kerja atau/dan prestasi akan dapat meningkatkan penglibatan pekerja dalam melaksanakan tugas dan tanggungjawab kerja harian. Natijahnya, penglibatan ini boleh pula mendorong mereka meningkatkan komitmen terhadap organisasi. Sungguhpun sifat perhubungan ini telah banyak dikaji, namun peranan penglibatan pekerja sebagai pemboleh ubah pengantara sangat kurang dibincangkan dalam kajian literatur tentang ganjaran organisasi. Oleh itu, kajian ini dilaksanakan untuk menilai hubungan di antara tahap ganjaran, penglibatan pekerja dan komitmen organisasi. Borang soal selidik telah digunakan untuk mengumpul data daripada pekerja di pusat-pusat latihan di Bandar Baru Bangi, Selangor. Keputusan pengujian hipotesis melalui analisis regresi stepwise menunjukkan bahawa hubungan antara tahap ganjaran dengan komitmen organisasi dipengaruhi secara tidak langsung oleh penglibatan pekerja dalam organisasi kajian. Selanjutnya, dapatan kajian ini boleh digunakan sebagai cadangan penting kepada pengamal untuk memahami kerumitan konsep penglibatan pekerja yang bersifat multi dimensi dan merangka polisi ganjaran yang adil bagi meningkatkan kelebihan daya saing and produktiviti organisasi dalam era persaingan global dan ekonomi yang tidak menentu.

Kata Kunci: Tahap ganjaran; penglibatan pekerja; komitmen organisasi; regresi stepwise

\section{ABSTRACT}

In an employee contribution perspective, reward level is often recognized as a significant instrument that may attract, motivate and retain competent employees to maintain and achieve the strategies and objectives of high competitive and performing organizations. Extant studies show that the ability of an organization to determine reward levels equally with job and/or performance criteria will strongly evoke employee engagement in performing daily tasks and responsibilities. As a result, this engagement may lead to a higher organizational commitment. Even though this relationship has extensively been researched, the role of employee engagement is not thoroughly discussed in the organizational reward literature. The aim of this research is to evaluate the relationship between reward level, employee engagement and organizational commitment. The survey questionnaires were used to gather data from employees at training centres at Bandar Baru Bangi, Selangor. The outcomes of testing research hypotheses using a stepwise regression analysis displayed that relationship between reward level and organizational commitment is indirectly affected by employee engagement in the studied organizations. Further, the result may be used as important recommendations to practitioners to understand the complexity of multi-dimensional employee engagement concept and to draw fair reward policies and procedures to enhance the competitive advantage and productivity of organizations in times of global competition and economy uncertainty.

Keywords: Reward level; employee engagement; organizational commitment; stepwise regression

\section{Pengenalan}

Perkembangan global dari segi politik (hubungan diplomatik dan perjanjian perniagaan antara negara), ekonomi (persaingan mendapatkan sumber dan perniagaan rentas sempadan), sosial (pekerja asing dan silang budaya) dan teknologi (telekomunikasi tanpa wayar) mendorong kebanyakan organisasi awam dan swasta untuk mengadakan transformasi institusi dan sikap bagi meningkatkan kelebihan berbanding dan prestasi operasi (Gills 2010; Rizescu \& Tileaga 2017). Transformasi ini telah menyebabkan berlakunya anjakan paradigm pengurusan, iaitu daripada berfokuskan kerja kepada pencapaian strategi organisasi (Azman \& Mohd Ridwan 2017; Newman et al. 2019). Di bawah paradigma baharu ini, majikan telah 
memperkasakan jabatan sumber manusia dengan autoriti pengstafan untuk merancang pembangunan bakat dan kompetensi pekerja bagi mengendalikan fungsi-fungsi sumber manusia dengan teratur, seperti program pampasan (Agarwal \& Al Qouyatahi 2018; Azman \& Mohd Ridwan 2017). Jabatan sumber manusia akan menubuhkan jawatankuasa yang melibatkan wakil-wakil daripada jabatan-jabatan yang lain, wakil-wakil pekerja atau kesatuan sekerja, dan perunding-perunding profesional untuk mereka bentuk program pampasan yang kreatif bagi mengiktiraf sumbangan pekerja (Azman \& Mohd Ridwan 2017; Newman et al. 2019).

Kajian tentang program ganjaran telah bermula semenjak dekad 60an dan mendapati bahawa ia merupakan antara penyumbang terbesar kepada peningkatan kos organisasi. Menyedari keadaan ini, program ganjaran perlu direka dengan rapi supaya ia menjadi instrumen yang berwibawa bagi mencapai matlamat dan strategi organisasi yang dinamik (Judge, et al. 2010; Yao et al. 2017). Martocchio dan Martocchio (2019) dan Newman et al. (2019) mengatakan bahawa program ganjaran yang efektif biasanya direka berpandukan ekuiti dalaman dan luaran organisasi. Ia mengambilkira empat prinsip utama: a) membentuk objektif program pampasan yang kreatif bagi meningkatkan kecekapan, keadilan, mematuhi undangundang dan peraturan, serta etika; b) menentukan jenis kelayakan ganjaran mengikut kebolehan organisasi untuk membayar; c) mengagihkan jenis, tahap atau/dan amaun ganjaran berdasarkan sumbangan pekerja; d) melaksanakan sistem dan kaedah pembahagian jenis, tahap atau/dan amaun ganjaran berdasarkan polisi organisasi; dan e) mengamalkan interaksi yang baik di antara pengurusan dan pekerja bagi meningkatkan kesejahteraan kerjaya pekerja. Keupayaan majikan melaksanakan program pampasan tersebut secara teratur akan dapat menarik, memotivasi dan mengekalkan pekerja yang kompeten untuk membantu menjayakan matlamat dan strategi organisasi dalam era ekonomi global (Aboramadan et al. 2020).

\section{PernyataAn Masalah}

Pemeriksaan yang teliti terhadap kajian literatur yang berkaitan dengan pengurusan sumber manusia mendapati bahawa program ganjaran yang dirancang dengan rapi tidak akan dapat mencapai tujuan sekiranya tahap ganjaran yang diberikan tidak setimpal dengan sumbangan pekerja (Bachkirov 2018; Holdener et al. 2020). Dalam konteks organisasi, tahap ganjaran kerap kali dikaitkan dengan jumlah pendapatan keseluruhan yang diterima oleh seseorang pekerja dan jumlah ini biasanya dikira secara tahunan (Newman et al. 2019). Apabila pekerja merasakan bahawa tahap ganjaran yang diterima daripada majikan adalah setimpal dengan sumbangannya, maka persepsi ini akan mendorong mereka mengamalkan gelagat yang positif, terutamanya penglibatan pekerja dalam melaksanakan fungsi-fungsi organisasi (Mukaihata et al.
2020; Holdener et al. 2020). Secara umumnya, penglibatan pekerja yang tinggi biasanya dikaitkan dengan pekerja yang mempunyai tahap keyakinan, kecerdasan, kegigihan, kegembiraan dan konsentrasi yang tinggi dalam menggunakan sumber-sumber yang ada untuk meningkatkan kecekapan dan keberkesanan organisasi (Maslach et al. 2001; Schaufeli et al. 2006).

Dalam era globalisasi, penglibatan pekerja telah diiktiraf sebagai faktor penentu kejayaan bagi organisasi yang berjaya (Holdener et al. 2020; Mukaihata et al. 2020). Beberapa kajian baharu yang diterbitkan dalam abad ke 21 mendedahkan bahawa hubungan di antara tahap ganjaran dan penglibatan pekerja pula boleh mendorong pekerja meningkatkan komitmen terhadap organisasi (Aboramadan et al. 2020; Bakker 2011). Dalam konteks ganjaran organisasi, kebanyakan pengkaji berpendapat bahawa tahap ganjaran, penglibatan pekerja dan komitmen organisasi adalah pemboleh ubah yang berlainan tetapi saling lengkap melengkapi satu sama lain (Mukaihata et al. 2020; Othman et al. 2019). Sebagai contoh, keupayaan majikan menentukan tahap ganjaran yang setimpal dengan sumbangan pekerja akan dapat meningkatkan penglibatan pekerja. Natijahnya, keadaan ini pula boleh membantu pekerja meningkatkan komitmen kepada organisasi (Aboramadan et al. 2020; Bakker 2011). Walaupun sifat hubungan ini telah dikaji secara meluas, namun peranan penglibatan pekerja sebagai pemboleh ubah pengantara masih kurang dibincangkan secara terperinci dalam kajian literatur tentang pampasan organisasi (Aboramadan et al. 2020; Othman et al. 2019).

Perbahasan di antara para pengkaji telah merumuskan bahawa keadaan ini mungkin dipengaruhi oleh faktor berikut: Pertama, kajian lepas terlalu banyak membincangkan ciri-ciri dalaman penglibatan kerja, seperti perbincangan secara konseptual tentang takrif, jenis dan signifikan penglibatan pekerja dalam organisasi perniagaan dan bukan perniagaan (Holdener et al. 2020; HulkkoNyman et al. 2014). Kedua, kajian lepas sangat kerap menggunakan model kesan langsung bagi mengukur hubungan antara dua konstruk, iaitu: a) kaitan antara tahap ganjaran dan penglibatan pekerja (Othman et al. 2019; Maden 2015); b) kaitan antara tahap ganjaran dan komitmen organisasi (Bakhirov 2018; Chew \& Chan 2008). Model kajian tersebut memadai diuji dengan menggunakan analisis statistik mudah dan hasil pengukurannya pula hanya berupaya melaporkan darjah keteguhan korelasi antara konstruk tersebut. Sebaliknya, ujian statistik tersebut tidak berupaya untuk mengukur saiz kesan dan sifat penglibatan pekerja sebagai pemboleh ubah pengantara yang penting dalam model kajian tersebut (Rai et al. 2019). Natijahnya, pendekatan kajian tersebut hanya berupaya mengemukakan cadangan-cadangan umum dan ia tidak memadai untuk memandu pengamal bagi memahami kerumitan konstruk penglibatan pekerja dan merangka pelan pengagihan ganjaran yang saksama untuk meningkatkan dan mengekalkan daya saing dan prestasi organisasi berasaskan pengetahuan (Aboramadan et al. 2020). 
Kajian ini menilai penetapan tahap ganjaran yang dilaksanakan di pusat-pusat latihan yang dikawalselia oleh kerajaan persekutuan Malaysia di Bandar Baru Bangi, Selangor. Sebagai organisasi awam, agensi ini mengamalkan polisi dan prosedur ganjaran yang ditentukan oleh sebuah agensi pusat kerajaan persekutuan Malaysia, iaitu Jabatan Perkhidmatan Awam. Sebagai contoh, kelayakan ganjaran dan kaedah pengagihan jenis, tahap atau/dan amaun ganjaran kewangan (seperti gaji dan bonus) dan bukan kewangan (seperti cuti, kesihatan, pinjaman dan persaraan) untuk semua pekerja dilakukan berdasar kriteria berikut: jawatan, lama berkhidmat, kekananan dan prestasi kerja (Jabatan Perkhidmatan Awam Malaysia 2019). Tujuan utama pelaksanaan sistem ganjaran ini adalah untuk menyampaikan perkhidmatan yang telus dan memperbaiki kepantasan bertindak bagi meningkatkan produktiviti organisasi (Jabatan Perkhidmatan Awam 2019; Unit Pemodenan Tadbiran dan Perancangan Pengurusan Malaysia 2018).

Untuk meningkatkan kecekapan pengurusan ganjaran, Jabatan Perkhidmatan Awam telah merangka tiga jenis penetapan tahap ganjaran untuk digunapakai oleh agensiagensi kerajaan, iaitu ganjaran berdasarkan keahlian organisasi (seperti cuti dan kemudahan rawatan), ganjaran berdasarkan status kerja (seperti jenis pekerjaan atau jawatan), ganjaran yang berbeza mengikut tahap kerja (seperti perbezaan pangkat), dan ganjaran yang berbeza mengikut prestasi pekerja (seperti merit) (Jabatan Perkhidmatan Awam Malaysia 2019). Kebanyakan pekerja berpuas hati bahawa polisi ganjaran tersebut telah dilaksanakan secara teratur maka keadaan ini dapat mendorong mereka meningkatkan penglibatan secara aktif (seperti usaha yang gigih, sanggup bekerja lebih masa dan mengejar pencapaian) dalam melaksanakan tugas dan tanggungjawab harian bagi menyumbang kepada kejayaan organisasi. Untuk memastikan penglibatan pekerja berlaku secara aktif dan beterusan, maka pihak pengurusan atasan telah menggunakan pendekatan yang standard bagi menambahbaik pengurusan agensi-agensi kerajaan, seperti mengadakan latihan yang berkaitan dengan gaya pengurusan berorientasi manusia dan menggalakkan budaya kerja berprestasi tinggi (Portal Rasmi Jabatan Perkhidmatan Awam 2020; Unit Pemodenan Tadbiran dan Perancangan Pengurusan Malaysia 2018). Sebagai contoh, gaya pengurusan berorientasi manusia dilaksanakan melalui kaedah pembuatan keputusan melalui perundingan dan penyertaan (seperti kumpulan mutu kerja dan mesyuarat), serta menyediakan sokongan material (seperti bajet dan peralatan) dan sokongan moral (seperti nasihat dan galakan untuk terus berusaha dengan gigih). Gaya pengurusan ini mendorong pengurus dan penyelia menggunakan kuasa dan pengaruh bagi meningkatkan penglibatan pekerja yang berkhidmat dalam pelbagai kategori dan peringkat perjawatan untuk menyelesaikan masalah kerja harian, memperbaiki prestasi kerja harian, menggalakkan pekerja memahirkan diri, mengembangkan pengetahuan dan mewujudkan gelagat yang positif semasa bertugas dalam organisasi (Jabatan Perkhidmatan Awam Malaysia 2019).

Manakala, budaya kerja berprestasi tinggi pula dilaksanakan melalui kaedah autonomi kerja (seperti kumpulan kerja diberikan kebebasan menggunakan daya kreatif dan membuat pertimbangan ke arah yang lebih baik) dan pembangunan kompetensi (seperti menggalakan latihan dan pembelajaran, mengaitkan prestasi dengan ganjaran, dan membuat pengambilan dan pemilihan staf yang kompeten bagi mengisi jawatan-jawatan penting). Kebanyakan pekerja menyokong pelaksanaan budaya kerja ini kerana ia dapat mendorong pengurus dan penyelia menggunakan kuasa dan pengaruh bagi mengurangkan karenah birokrasi dalam membuat keputusan yang penting dan menyelesaikan aduan pekerja. Keadaan yang positif ini boleh pula mendorong pekerja yang berkhidmat dalam hierarki yang berbeza untuk melibatkan diri secara aktif dalam menilai keperluan latihan, menggariskan pelan operasi tahunan latihan, membuat belanjawan, peka dengan kehendak pelanggan dan seterusnya membantu mencapai matlamat dan misi organisasi (Portal Rasmi Jabatan Perkhidmatan Awam Malaysia 2020).

Pemerhatian yang lebih mendalam terhadap gelagat pekerja mendapati bahawa kepuasan terhadap penglibatan tersebut telah mendorong mereka untuk meningkatkan gelagat yang positif, seperti komitmen organisasi. Amalan komitmen organisasi biasanya diperlihatkan oleh pekerja dalam tiga aspek berikut: Pertama, perubahan emosi pekerja menjadi semakin positif terhadap organisasi. Sebagai contoh, pekerja merasa gembira, memuji dan bangga sebagai ahli organisasi. Kedua, perubahan tingkah laku pekerja menjadi semakin bertanggungjawab terhadap organisasi. Sebagai contoh, pekerja merasa terhutang budi dan setia dengan kebaikan organisasi, serta dapat menyesuaikan diri dengan nilai-nilai yang dipegang oleh organisasi. Ketiga, keterikatan pekerja dengan organisasi adalah tidak berubah walau pun berlaku transformasi organisasi. Sebagai contoh, pekerja merasakan perubahan struktur organisasi (seperti pusingan kerja, perluasan kerja dan pengkayaan kerja) adalah tidak merugikan atau menganiaya mereka dan keadaan ini mendorong untuk kekal berkhidmat sehingga tempoh persaraan. Sungguhpun sifat perhubungan ini adalah imperatif, namun peranan penglibatan pekerja sebagai pemboleh ubah pengantara tidak banyak diketahui kerana kekurangan penerbitan kajian lepas di agensi-agensi Kerajaan Persekutuan Malaysia (Asri \& Hamrila 2007; Muhamad Ariff et al. 2018). Oleh yang demikian, keadaan di atas memberi inspirasi kepada pengkaji untuk melengkapkan kelompangan dalam kajian literatur dengan menilai peranan penglibatan pekerja sebagai pemboleh ubah pengantara antara tahap ganjaran dan komitmen organisasi.

Sungguhpun hubungan antara tahap ganjaran, penglibatan pekerja dan komitmen organisasi adalah sangat penting, namun peranan penglibatan pekerja sebagai pemboleh ubah pengantara tidak banyak diketahui kerana kajian empirikal di organisasi kajian adalah sangat terhad. 
Seterusnya, keadaan memberi inspirasi kepada pengkaji untuk melengkapkan kelompangan dalam kajian literatur dengan menilai peranan penglibatan pekerja sebagai pemboleh ubah pengantara antara tahap ganjaran dan komitmen organisasi. Secara khususnya, tujuan kajian ini dilaksanakan untuk mengukur tiga jenis hubungan: Pertama, mengukur hubungan di antara tahap ganjaran dengan komitmen organisasi. Kedua, mengukur hubungan di antara tahap ganjaran dengan penglibatan pekerja. Ketiga, mengukur hubungan di antara tahap ganjaran, penglibatan pekerja dan komitmen organisasi. Selanjutnya, struktur perbincangan artikel ini menyentuh lima aspek yang penting: kajian literatur, metodologi, dapatan, perbincangan dan kesimpulan.

\section{KAJIAN LiTERATUR}

TAHAP GANJARAN

Newman et al. (2019) mentakrifkan tahap ganjaran secara umum sebagai purata susunan kadar ganjaran yang ditetapkan untuk setiap pekerjaan dalam sesebuah organisasi. Ia dikira dengan cara mencampurkan gaji asas dengan bonus, faedah dan nilai pegangan stok, dan dibahagikan pula dengan bilangan pekerja. Tahap ganjaran yang berbeza di antara pekerja biasanya diterangkan dengan jelas dalam bentuk jumlah pendapatan tahunan. Dalam kebanyakan organisasi, tahap ganjaran ditentukan mengikut tiga jenis polisi ganjaran, iaitu lead policy (tahap ganjaran diberikan kepada pekerja melebihi tahap ganjaran yang diberikan oleh organisasi pesaing), match policy (tahap ganjaran diberikan kepada pekerja sama atau mengikut tahap ganjaran yang diberikan oleh organisasi pesaing), dan lag policy (tahap ganjaran diberikan kepada pekerja lebih rendah daripada tahap ganjaran yang diberikan oleh organisasi pesaing). Lead policy biasanya diamalkan untuk menarik pekerja yang mempunyai tahap kompetensi yang tinggi; match policy kerap digunakan untuk menarik pekerja yang mempunyai tahap kompetensi yang sederhana, dan lag policy sering dilakukan untuk menarik pekerja yang mempunyai kemahiran yang rendah. Sesebuah organisasi lazimnya mengamalkan ketiga-tiga jenis polisi tersebut dalam penentuan tahap ganjaran kepada pekerja untuk meningkatkan daya saing luaran organisasi (Martocchio \& Martocchio 2019; Newman et al. 2019). Kajian yang dilaksanakan baru-baru ini menyokong bahawa penentuan tahap ganjaran yang setimpal dengan sumbangan pekerja dapat meningkatkan gelagat yang positif, terutamanya komitmen organisasi (Bachkirov 2018; Chew \& Chan 2008) dan penglibatan pekerja (Holdener et al. 2020; Rai et al. 2019).

\section{PENGLIBATAN PEKERJA}

Rothbard (2001) menafsirkan penglibatan pekerja secara umum sebagai satu ciri psikologi positif yang berkaitan dengan kerja, seperti individu mempunyai kesanggupan yang sebenar untuk menyumbang kepada kejayaan organisasi (Albrecht 2010), melawan kelesuan emosi dan mempamerkan tenaga dan keyakinan diri yang tinggi (Leiter \& Maslach 2001), menunjukkan tahap kecergasan dan kegembiraan yang tinggi (Maslach et al. 2001), dan mempunyai tahap kegigihan, dedikasi dan keasyikan yang tinggi untuk mengejar sesuatu objektif yang sangat mencabar (Schaufeli et al. 2006). Seterusnya, tahap penglibatan ini boleh menggerakkan mereka untuk menjayakan sasaran-sasaran yang ditetapkan dalam pelanpelan taktikal dan strategi organisasi (Martocchio \& Martocchio 2019; Othman et al. 2019). Kajian terbaharu mendapati bahawa penglibatan pekerja adalah satu bentuk reaksi pekerja terhadap pemberian tahap ganjaran yang diberikan oleh majikan (Mukaihata et al. 2020; Othman et al. 2019) dan ia juga boleh bertindak sebagai pemboleh ubah pengantara dalam hubungan di antara tahap ganjaran dan komitmen organisasi (Aboramadan et al. 2020; Rai et al. 2019).

\section{KOMITMEN ORGANISASI}

Mowday et al. (1979) dan Rehman et al. (2012) mentakrifkan komitmen organisasi secara umum sebagai keterikatan individu secara psikologi dengan organisasi. Sebagai contoh, keterikatan ini sering kali ditunjukkan oleh seseorang individu apabila ia boleh menerima, menginternalisasi, dan melihat tanggungjawabnya berdasarkan hasrat dan matlamat organisasi. Takrif komitmen ini adalah bersifat umum dan sukar diukur dengan jelas. Kemudiannya, konsep komitmen organisasi telah diperjelaskan oleh Allen dan Meyer (1990) dalam Teori Tiga Dimensi Komitmen Organisasi. Teori ini menerangkan bahawa gabungan di antara komitmen afektif (emosi positif, pengiktirafan dan penglibatan dengan organisasi), komitmen normatif (rasa bertanggungjawab terhadap organisasi) dan kalkulatif (rasa memperolehi banyak faedah jika terus berkhidmat dengan organisasi). Pekerja yang mempunyai tahap komitmen afektif, komitmen normatif dan komitmen kalkulatif yang tinggi akan terasa lebih tinggi keterikatan dengan organisasi (Allen \& Meyer 1996; Khattak et al. 2017). Kajian yang terkini mendapati bahawa komitmen organisasi adalah satu bentuk tindak balas pekerja terhadap pemberian tahap ganjaran oleh majikan (Bachkirov 2018; Rai et al. 2019) dan ia juga merupakan kesan penting yang terhasil daripada perhubungan di antara tahap ganjaran dan komitmen organisasi (Aboramadan et al. 2020; Rai et al. 2019).

\section{Hipotesis Dan KerangKa KaJian}

PERHUBUNGAN ANTARA TAHAP GANJARAN DAN GELAGAT PEKERJA

Pengaruh tahap ganjaran dalam mengubah gelagat pekerja adalah selari dengan saranan yang dikemukakan oleh Teori Ekuiti (Adam 1963), Teori Jangkaan (Vroom 1964) dan 
Teori Diskrepensi (Lawler 1971, 1981). Sebagai contoh, Teori Ekuiti (Adam 1963) mencadangkan bahawa pemberian tahap ganjaran (output) yang setimpal dengan sumbangan pekerja (seperti usaha) adalah satu bentuk layanan pengurusan yang adil dan amalan ini dapat meningkatkan gelagat yang positif. Manakala, Teori Jangkaan (Vroom 1964) mengatakan bahawa seseorang pekerja yang dapat meramalkan dengan jelas bahawa tindakannya akan menghasilkan sesuatu kesan yang bernilai (seperti ganjaran) maka keadaan ini akan mendorong beliau mengamalkan gelagat positif. Seterusnya, Teori Diskrepensi (Lawler 1971, 1981) mengenengahkan bahawa seseorang pekerja akan merasa puas hati apabila dia menerima tahap ganjaran sama dengan pengharapannya maka keadaan ini akan mendorong beliau melakukan tindakan yang positif. Aplikasi teori tersebut dalam pengurusan ganjaran menunjukkan bahawa konsep ekuiti, jangkaan dan diskrepensi kerap kali diterjemahkan sebagai tahap ganjaran. Saranan teori tersebut mendapat sokongan daripada artikel-artikel yang berkaitan dengan ganjaran organisasi (Fink et al. 2019; Holdener et al. 2020).

Kebanyakan kajian dahulu sangat kurang menilai tahap ganjaran, tetapi sangat banyak mengenengahkan jenis ganjaran yang disediakan mengikut kelayakan pekerja, seperti gaji asas, faedah, ganjaran kontingensi dan keadaan pekerjaan (seperti autonomi dan keanjalan masa kerja) (Haar \& Spell 2009; Korir \& Kipkebut 2016; Salwa et al. 2015). Jenis ganjaran ini sering dikaitkan dengan gelagat pekerja yang positif, terutamanya komitmen organisasi (Korir \& Kipkebut 2016; Salwa et al. 2015) dan penglibatan pekerja (Brown \& Reilly 2013; Hoole \& Hotz 2016). Kajian ini mendedahkan jenis ganjaran kewangan dan bukan kewangan atau ganjaran intrinsik dan ekstrinsik adalah keperluan asas yang sangat penting untuk meningkatkan dan mengekalkan motivasi kerja, komitmen organisasi, tingkah laku kewarganegaraan organisasi, kepuasan kerja dan menghalang keinginan untuk berhenti kerja (Haar \& Spell 2009; Hoole \& Hotz 2016; Korir \& Kipkebut 2016).

Sebaliknya, kajian baharu menyokong peranan tahap ganjaran sebagai pemboleh ubah peramal yang boleh mengubah gelagat pekerja yang negatif kepada positif. Sebagai contoh, beberapa kajian berdasarkan model kesan langsung telah dilaksanakan mengguna sampel organisasi yang berlainan, seperti tanggapan 13 pakar, 12 pengurus sumber manusia dan 457 pekerja di organisasi-organisasi di Australia (Chew \& Chan 2008), tanggapan 633 pelajar program perakaunan professional (Scott et al. 2011), tanggapan 154 pekerja di organisasi penjagaan orang tua Finland dan 137 pekerja di tujuh organisasi penjagaan orang tua di Itali (Hulkko-Nyman et al. 2014), tanggapan 240 pekerja berbangsa Turki di lima buah organisasi yang mengamalkan penglibatan tinggi dalam pengurusan sumber manusia (Maden 2015), tanggapan 880 pekerja dalam konteks bukan negara Barat (Bachkirov 2018), tanggapan 761 pekerja di 17 cawangan daripada tujuh bank swasta di negeri Uttar Pradesh (Rai et al. 2019), tanggapan 150 pekerja di sebuah syarikat pembinaan di wilayah selatan
Malaysia (Othman et al. 2019), tanggapan 425 jururawatjururawat psikiatrik berbangsa Jepun (Mukaihata et al. 2020), tanggapan 105 responden di sebuah hospital di Wisconsin (Fink et al. 2019), dan tanggapan 73 pengguna e-kesihatan di Jerman (Holdener et al. 2020). Dapatan kaji selidik tersebut mengesahkan bahawa bahawa keupayaan majikan menentukan tahap ganjaran (seperti, penetapan gaji, bonus dan faedah sampingan) sepadan dengan sumbangan pekerja (seperti pekerjaan atau/dan merit) telah memberi impak yang positif terhadap gelagat pekerja, terutamanya meningkatkan komitmen organisasi (Bachkirov 2018; Chew \& Chan 2008; Rai et al. 2019; Scott et al. 2011) dan penglibatan pekerja (Holdener et al. 2020; Hulkko-Nyman et al. 2014; Maden 2015; Mukaihata et al. 2020; Rai et al. 2019; Othman et al. 2019). Oleh itu, hipotesis-hipotesis yang dicadangkan ialah:

$\mathrm{H}_{1}$ : Terdapat hubungan yang positif di antara tahap ganjaran dan komitmen organisasi

$\mathrm{H}_{2}$ : Terdapat hubungan yang positif di antara tahap ganjaran dan penglibatan pekerja

PERHUBUNGAN ANTARA TAHAP GANJARAN, PENGLIBATAN PEKERJA DAN KOMITMEN ORGANISASI

Pengaruh penglibatan pekerja sebagai pemboleh ubah pengantara adalah konsisten dengan saranan yang dikemukakan oleh Teori Penglibatan Peribadi (Kahn 1992), Teori Penglibatan Kerja (Maslach \& Leiter 1997), Teori Penglibatan Kerja (Schaufeli et al. 2002) dan Model Tuntutan Kerja-Sumber (Bakker 2011; Bakker \& Demerouti 2008). Penglibatan pekerja adalah konstruk yang telah diubahsuai daripada Teori Penglibatan Peribadi (Kahn 1992), yang menerangkan bahawa penglibatan individu merangkumi aspek fizikal, emosi dan kognitif ketika dalam melaksanakan kerja (Remo 2012). Kemudiannya, saranan yang diutarakan oleh Kahn (1992) telah dikaitkan dengan persekitaran organisasi maka lahirlah beberapa teori penglibatan organisasi yang penting, iaitu Teori Penglibatan Kerja (Maslach \& Leiter 1997), Teori Penglibatan Kerja (Schaufeli et al. 2002) dan Model Tuntutan Kerja-Sumber (Bakker 2011; Bakker \& Demerouti 2008). Sebagai contoh, Teori Penglibatan Kerja (Maslach \& Leiter 1997) mengenengahkan bahawa penglibatan pekerja dengan menggunakan tenaga yang kuat dalam melaksanakan operasi kerja dapat membantu meningkatkan gelagat yang positif. Manakala, Teori Penglibatan Kerja (Schaufeli et al. 2002) menerangkan bahawa penglibatan pekerja dibina berdasarkan tiga ciri emosi, minda dan gelagat pekerja: a) kekuatan (tahap daya tahan tenaga dan mental yang tinggi, kesanggupan untuk meningkatkan daya usaha dalam sesuatu kerja, dan tabah dalam menghadapi kesukaran kerja; b) kegigihan (melibatkan diri dengan serius dalam sesuatu kerja, dan merasai kepentingan, berinspirasi, bersemangat dan memenuhi tuntutan kerja); dan c) keasyikan (memberi konsentrasi yang tinggi, gembira dengan kerja, dan tidak menyedari masa berlalu dengan pantas). Tiga ciri ini 
berupaya mendorong pekerja untuk mempamerkan gelagat yang positif. Selanjutnya, Model Tuntutan Kerja-Sumber (Bakker 2011; Bakker \& Demerouti 2008) menghuraikan bahawa penglibatan pekerja berlaku apabila pekerja dapat menggunakan sumber pekerjaan (aspek-aspek kerja yang meningkatkan motivasi, membantu mencapai tujuan organisasi, dan memenuhi tuntutan kerja seperti ganjaran, kawalan kerja dan sokongan sosial) dan sumber peribadi (aspek-aspek peribadi pekerja yang mempunyai daya tahan dan kebolehan untuk berjaya dalam kerja) dalam menghadapi cabaran-cabaran semasa bagi mencapai hasil kerja yang disasarkan. Amalan penglibatan ini pula boleh mendorong pekerja mempamerkan gelagat yang positif dalam organisasi. Aplikasi teori ini dalam pengurusan ganjaran menunjukkan bahawa pemboleh ubah penglibatan pekerja sering kali dianggap sebagai pemboleh ubah pengantara yang penting dalam hubungan di antara tahap ganjaran dan gelagat yang positif, seperti komitmen organisasi (Aboramadan et al. 2020).

Kebanyakan kajian dahulu menilai peranan penglibatan pekerja dalam meningkatkan kesan jenis ganjaran (seperti ganjaran kewangan, penghargaan, faedah dan persekitaran kerja) dan jenis komitmen organisasi yang tertentu seperti komitmen afektif (Scrima et al. 2014) dan komitmen normatif (Ghosh et al. 2016). Kajian ini mendedahkan bahawa penglibatan pekerja berdasarkan keinginan untuk menerima jenis ganjaran kewangan dan bukan kewangan atau ganjaran intrinsik dan ekstrinsik hanya berupaya mendorong mereka meningkatkan komitmen organisasi tertentu sahaja, iaitu komitmen afektif (sekadar merasa bangga dengan organisasi) (Scrima et al 2014), dan komitmen normatif (sekadar merasa bertanggungjawab terhadap organisasi) (Ghosh et al. 2016).

Sebaliknya, kajian yang dilaksanakan berdasar model kesan tidak langsung mengiktiraf peranan penglibatan pekerja sebagai pemboleh ubah pengantara yang penting dalam hubungan antara tahap ganjaran dan komitmen organisasi. Sebagai contoh, beberapa kajian empirikal telah dilaksanakan berdasarkan model tersebut menggunakan saiz sampel yang berbeza, seperti tanggapan 761 responden yang berkhidmat di 17 cawangan dalam 7 bank-bank swasta di negeri Uttar Pradesh, India (Rai et al. 2019), dan tanggapan 237 staf akademik dan pentadbiran di universitiuniversiti di Palestin (Aboramadan et al. 2020). Dapatan kaji selidik mereka membuktikan bahawa keupayaan majikan menentukan tahap ganjaran (seperti, penetapan gaji, bonus, insentif, faedah bukan kewangan dan faedah psikologi) yang setimpal dengan sumbangan pekerja (seperti jawatan, lama berkhidmat, kekananan dan merit) dapat meningkatkan penglibatan pekerja dalam melaksanakan tugas dan tanggungjawab kerja harian. Seterusnya, penglibatan ini pula boleh mendorong mereka untuk meningkatkan komitmen dengan organisasi (Aboramadan et al. 2020; Rai et al. 2019). Oleh itu, hipotesis yang dicadangkan ialah:

$\mathrm{H}_{3}$ : Hubungan tahap ganjaran dengan komitmen organisasi adalah dipengaruhi secara tidak langsung oleh penglibatan pekerja

Kajian literatur di atas telah digunakan sebagai panduan untuk membina kerangka kajian seperti yang diterangkan dalam Rajah 1. Ia menunjukkan tahap ganjaran sebagai pemboleh ubah tidak bersandar, penglibatan pekerja sebagai pemboleh ubah pengantara, dan komitmen organisasi sebagai pemboleh ubah bersandar. Hubungan ini menerangkan bahawa kesan tahap ganjaran ke atas komitmen organisasi adalah dipengaruhi secara tidak langsung oleh penglibatan pekerja.

\section{REKA BENTUK KAJIAN}

Kajian ini dijalankan di pusat-pusat latihan yang dikawal selia oleh kerajaan persekutuan Malaysia di Bandar Baru Bangi, Selangor. Kaedah kaji selidik telah digunakan sebagai strategi penyelidikan dan ia membenarkan pengkaji menggumpul data borang soal selidik menggunakan aplikasi "google form". Prosedur ini amat berguna untuk membantu pengkaji menggumpulkan data dengan lebih tepat, kurang pilih kasih, dan berkualiti (Creswell 2016). Sebagai langkah pertama dalam pengumpulan data, pengkaji telah menyediakan borang soal selidik berdasarkan kajian literatur yang berkaitan dengan pampasan organisasi. Seterusnya, teknik terjemahan balik telah digunakan untuk menterjemah soalan-soalan soal selidik ke bahasa Melayu dan Bahasa Inggeris. Penggunaan teknik penterjemahan ini adalah untuk memastikan ketepatan dan keboleh percayaan instrumen kajian (Creswell 2016).

Borang soal selidik kajian ini mengandungi 3 bahagian: Pertama, tahap ganjaran (TGJN) dinilai berdasarkan 12 item yang diadaptasikan daripada kajian literatur berkaitan dengan pampasan organisasi (Newman et al. 2019; Hulkko-Nyman et al. 2014; Rai et al. 2019).

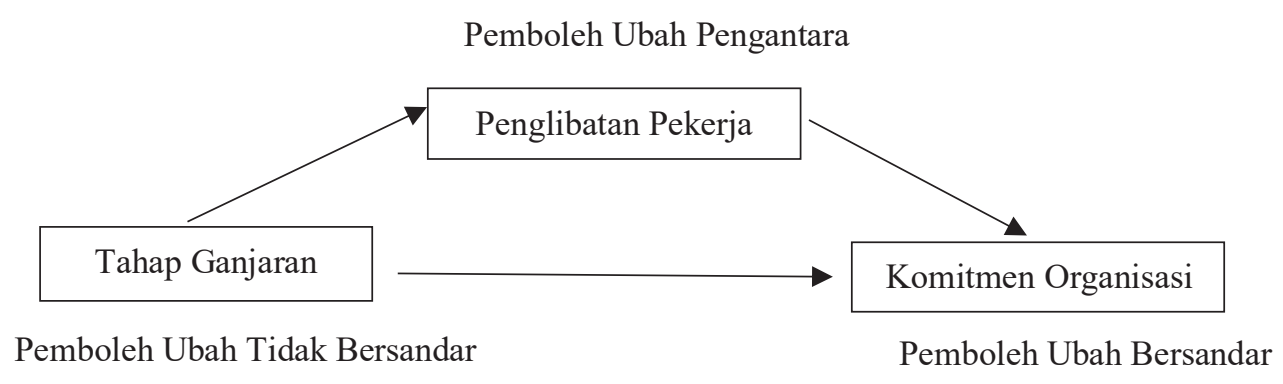

RAJAH 1. Kerangka Kajian 
Konstruk ini diukur menggunakan dua dimensi, iaitu tahap ganjaran kewangan dan tahap ganjaran bukan kewangan. Kedua, penglibatan pekerja dinilai berdasarkan 14 item yang diadaptasikan daripada kajian literatur yang berkaitan dengan penglibatan organisasi (Fletcher \& Robinson 2013; Schaufeli \& Bakker 2003). Konstruk ini diukur menggunakan tiga dimensi, iaitu kekuatan, dedikasi dan penyerapan. Ketiga, komitmen organisasi dinilai berdasarkan 9 item yang diadaptasikan daripada kajian literatur berkaitan dengan komitmen organisasi (Allen \& Meyer 1990, 1996). Konstruk ini diukur menggunakan tiga dimensi, iaitu komitmen afektif, komitmen normatif dan komitmen kalkulatif. Kesemua item tersebut telah dinilai mengikut skala 5 jawapan pilihan, iaitu bermula daripada "sangat tidak setuju" (1) hingga "sangat setuju" (5). Ciriciri demografi responden telah digunakan sebagai pemboleh ubah kawalan kerana kajian ini hanya menumpukan kepada sikap pekerja.

Unit analisis kajian ini adalah pekerja yang berkhidmat di organisasi kajian. Teknik pensampelan bertujuan telah digunakan untuk mengedarkan 150 borang soal selidik kepada pekerja yang terdiri daripada berbagai peringkat dan kategori perjawatan yang berkhidmat di bahagian/ jabatan yang berlainan dalam organisasi kajian. Secara khususnya, teknik pensampelan ini dipilih kerana pihak pengurusan organisasi tidak dapat memberikan senarai pekerja yang lengkap atas alasan sulit dan ingin menjaga reputasi serta imej korporat organisasi. Oleh itu, keadaan ini menyebabkan pengkaji tidak dapat menggunakan kaedah rawak untuk memilih responden kajian. Daripada jumlah borang soal selidik yang telah diedarkan, hanya 117 (78\%) borang yang dijawab dengan lengkap telah dikembalikan kepada pengkaji. Kesemua responden ini menjawab borang soal selidik dengan kerelaan, kerahsiaan dan tanpa paksaan.

Seterusnya, kecukupan sampel kajian ini telah duji berdasarkan rule of thumb, iaitu hukum 10 kali ganda. Hukum ini menegaskan bahawa bilangan laluan penstrukturan yang paling besar berhubung dengan konstruk tertentu dalam model penstrukturan perlu sama atau lebih besar daripada 10 (Hair et al. 2006). Dalam model penstrukturan kajian ini, terdapat tiga arah laluan, iaitu anak panah daripada tahap ganjaran ke penglibatan pekerja, arah panah daripada penglibatan pekerja ke komitmen organisasi dan anak panah daripada tahap ganjaran ke komitmen organisasi. Berdasarkan hukum ini, saiz sampel yang patut diambil sekurang-kurangnya 30 responden (3 anak panah x 10). Oleh itu, sampel kajian ini telah memenuhi kriteria di atas, dan layak digunakan untuk menilai hipotesis kajian. Bagi menguji unsur-unsir pilih kasih dalam borang soal selidik, maka ujian Harman's Single Factor seperti yang disyorkan oleh Padsakoff et al. (2003) telah dilaksanakan. Keputusan ujian ini memaparkan bahawa nilai varian adalah 46\%, iaitu kurang daripada nilai 50\% (Padsakoff et al. 2003). Ini bermakna unsur bias dalam borang soal selidik adalah tidak kritikal.

Pakej Statistik untuk Sains Sosial (SPSS) telah digunakan untuk menganalisis data kajian seperti yang disyorkan oleh Hair et al. (2006). Prosedur analisis data ini ialah: Pertama, analisis terokaan faktor digunakan untuk menilai kesahan dan keboleh percayaan instrumen kajian. Kedua, statistik deskriptif dan analisis korelasi Pearson digunakan untuk mengesan masalah kolineariti. Ketiga, analisis regresi linear yang mudah telah digunakan untuk mengukur model kesan langsung dan analisis regresi stepwise pula telah digunakan untuk mengukur model pemboleh ubah pengantara. Akhir sekali, nilai $\mathrm{R}^{2}$ digunakan untuk menentukan kesan model kajian berdasarkan kriteria berikut: kesan yang besar (0.26), kesan yang sederhana (0.13) and kesan yang lemah (0.02) (Cohen 1988).

\section{Dapatan, Perbincangan dan ImPliKasi}

\section{CIRI-CIRI RESPONDEN}

Jadual 1 menunjukkan bahawa kebanyakan responden berumur di antara 21 tahun dan 30 tahun (59.8\%), perempuan $(59.8 \%)$, berkelulusan ijazah sarjana muda (40.2\%), bujang $(54.7 \%)$, telah berkhidmat daripada 1 tahun hingga 5 tahun (58.1\%), dan berpendapatan bulanan antara RM1,000 dan RM2,499 (36.8\%).

\section{KESAHAN DAN KEBOLEHPERCAYAAN INSTRUMEN}

Jadual 2 menunjukkan keputusan analisis faktor bagi itemitem yang mewakili setiap konstruk, dan Jadual 3 pula menunjukkan kesahan dan kebolehpercayaan instrumen. Ujian ini telah dilaksanakan berdasarkan prosedur yang disarankan oleh Hair et al. (2006) dan Nunally dan Bernstein (1994). Analisis faktor terokaan telah dilakukan terhadap 17 item yang mewakili tiga konstruk, iaitu tahap ganjaran (TGJN) (4 item), penglibatan pekerja (PGLN) (9 item), dan komitmen organisasi (KOTM) (4 item). Keputusan analisis ini menunjukkan empat dapatan penting: Pertama, ujian Kaiser Mayer-Olkin (KMO) telah dilakukan untuk menentukan kecukupan sampel kajian. Hasil ujian ini mendapati bahawa semua konstruk mempunyai nilai KMO lebih tinggi daripada 0.60 dan nilai ujian sferasiti Bartlett adalah signifikan. Ini menunjukkan bahawa sampel kajian ini mencukupi untuk digunakan dalam pengujian hipotesis (Hair et al. 2006; Nunally \& Bernstein 1994). Kedua, item-item yang mewakili setiap konstruk mempunyai muatan faktor melebihi 0.40 , menunjukkan semua kontruk telah mencapai tahap kesahan item (Hair et al. 2006; Nunally \& Bernstein 1994). Ketiga, semua konstruk mempunyai nilai eigen yang melebihi 1.0, dan nilai penerangan varian melebihi 45 peratus. Dapatan ini menunjukkan bahawa semua konstruk telah mencapai tahap kesahan yang ditetapkan. Akhir sekali, semua konstruk mempunyai nilai Cronbach Alpha melebihi 0.80, menunjukkan bahawa semua konstruk mencapai tahap konsisten dalaman yang tinggi. Keseluruhannya, keputusan analisis statistik ini mengesahkan bahawa instrumen kajian telah mencapai tahap kesahan dan kebolehpercayaan yang ditetapkan. 
JADUAL 1. Ciri-ciri responden kajian

\begin{tabular}{|c|c|c|c|}
\hline Profil Responden & Sub-Profil & Kekerapan & Peratusan $(\%)$ \\
\hline \multirow[t]{4}{*}{ Umur } & 21 hingga 30 tahun & 70 & 59.8 \\
\hline & 31 hingga 40 tahun & 22 & 18.8 \\
\hline & 41 hingga 50 tahun & 13 & 11.1 \\
\hline & 51 hingga 60 tahun & 12 & 10.3 \\
\hline \multirow[t]{2}{*}{ Jantina } & Lelaki & 47 & 40.2 \\
\hline & Perempuan & 70 & 59.8 \\
\hline \multirow[t]{6}{*}{ Tahap Pendidikan } & PMR & 2 & 1.7 \\
\hline & SPM & 15 & 12.8 \\
\hline & STPM / Diploma & 43 & 36.8 \\
\hline & Ijazah Sarjana Muda & 47 & 40.2 \\
\hline & Ijazah Sarjana & 8 & 6.8 \\
\hline & $\mathrm{PhD}$ & 2 & 1.7 \\
\hline \multirow[t]{3}{*}{ Status Perkahwinan } & Bujang & 64 & 54.7 \\
\hline & Berkahwin & 49 & 41.9 \\
\hline & Duda / Janda & 4 & 3.4 \\
\hline \multirow[t]{5}{*}{ Tempoh Perkhidmatan } & 1 hingga 5 tahun & 68 & 58.1 \\
\hline & 6 hingga 10 tahun & 12 & 10.3 \\
\hline & 11 hingga 15 tahun & 12 & 10.3 \\
\hline & 16 hingga 20 tahun & 9 & 7.7 \\
\hline & 21 hingga 25 tahun keatas & 16 & 13.7 \\
\hline \multirow[t]{6}{*}{ Pendapatan Bulanan } & Kurang RM1,000 & 17 & 14.5 \\
\hline & RM 1,000 - RM 2,499 & 43 & 36.8 \\
\hline & RM 2,500 - RM 3,999 & 30 & 25.6 \\
\hline & RM4,000 - RM 5,499 & 5 & 4.3 \\
\hline & RM 5,500 - RM 6,999 & 10 & 8.5 \\
\hline & RM 7,000 ke atas & 12 & 10.3 \\
\hline
\end{tabular}

Jadual 4 menunjukkan keputusan ujian statistik deskriptif dan analisis kolerasi Pearson. Nilai min bagi semua konstruk berada di antara 3.4936 dan 4.0665 , bererti tahap TGJN, PGLN dan KOTM bermula daripada tahap tinggi (3) hingga sangat tinggi (5). Nilai pekali kolerasi bagi hubungan di antara pemboleh ubah tidak bersandar (TGJN) dan pemboleh ubah pengantara (PGLN), dan hubungan di antara pemboleh ubah pengantara (PGLN) dan pemboleh ubah bersandar (KOTM) adalah kurang daripada 0.90. Dapatan ini menunjukkan bahawa semua konstruk adalah bebas daripada masalah kolineariti (Hair et al. 2006). Secara keseluruhannya, dapatan statistik ini mengesahkan sekali lagi bahawa instrumen kajian ini telah mencapai tahap kesahan dan kebolehpercayaan yang ditetapkan.

\section{DAPATAN PENGUJIAN H1}

Jadual 5 menunjukkan bahawa kemasukan TGJN ke dalam analisis telah menerangkan perubahan varian dalam KOTM sebanyak 38 peratus. Nilai $\mathrm{R}^{2}$ ini menerangkan bahawa model kajian ini mempunyai kesan yang besar (Cohen 1988). Manakala, nilai faktor inflasi varian bagi hubungan di antara TGJN dan KOTM ialah 1.000, iaitu lebih kecil daripada 10.0. Ini menunjukkan bahawa TGJN adalah bebas daripada masalah kolineariti (Hair et al. 2006). Seterusnya, keputusan pengujian hipotesis menunjukkan bahawa hubungan di antara TGJN dan KOTM adalah signifikan ( $\beta=0.614, p<0.001)$. Oleh itu, H1 disokong. Dapatan ini mengesahkan bahawa keupayaan pihak pengurusan menentukan tahap ganjaran setimpal dengan sumbangan pekerja dapat meningkatkan komitmen organisasi.

\section{DAPATAN PENGUJIAN H2}

Jadual 6 menunjukkan bahawa kemasukan TGJN ke dalam analisis telah menerangkan perubahan varian dalam PGLN sebanyak 30 peratus. Nilai $\mathrm{R}^{2}$ ini menerangkan bahawa model kajian ini mempunyai kesan yang besar (Cohen 1988). Manakala, nilai faktor inflasi varian bagi hubungan di antara TGJN dan PGLN ialah 1.000, iaitu lebih kecil daripada 10.0. Ini menunjukkan bahawa TGJN adalah bebas daripada masalah kolineariti (Hair et al. 2006). Seterusnya, keputusan pengujian hipotesis menunjukkan bahawa hubungan antara TGJN dan PGLN adalah signifikan $(\beta=.548, \mathrm{p}<0.001)$. Oleh itu, H2 disokong. Dapatan ini 
JADUAL 2. Analisis faktor

\begin{tabular}{|c|c|c|c|c|}
\hline \multirow[t]{2}{*}{ Konstruk } & \multirow{2}{*}{$\begin{array}{l}\text { Bilangan } \\
\text { Item }\end{array}$} & \multicolumn{3}{|c|}{ Muatan faktor } \\
\hline & & TGJN & PGLN & KOTM \\
\hline TGJN & 4 & & & \\
\hline Saya berasa berpuas hati dengan faedah-faedah yang diterima di tempat kerja. & & & .851 & \\
\hline $\begin{array}{l}\text { Saya percaya bahawa gaji yang saya peroleh setimpal dengan kerja yang saya } \\
\text { lakukan. }\end{array}$ & & & .753 & \\
\hline Gaji yang saya peroleh diberi dengan adil. & & & .786 & \\
\hline Syarikat akan memberi bonus kepada pekerja. & & & .723 & \\
\hline PGLN & 9 & & & \\
\hline Saya bersungguh-sungguh dalam melakukan kerja. & & .906 & & \\
\hline Saya berasa bersemangat untuk melakukan tugasan yang baru diberikan. & & .784 & & \\
\hline Saya sukakan cabaran dalam melakukan tugasan saya. & & .866 & & \\
\hline $\begin{array}{l}\text { Saya akan melibatkan diri dalam aktiviti / program yang dijalankan di tempat } \\
\text { kerja. }\end{array}$ & & .849 & & \\
\hline $\begin{array}{l}\text { Saya boleh melakukan pelbagai tugas yang diberikan supaya dapat menambah } \\
\text { pengetahuan dan pengalaman. }\end{array}$ & & .905 & & \\
\hline $\begin{array}{l}\text { Saya akan membantu rakan sekerja sekiranya mereka memerlukan pertolongan } \\
\text { saya. }\end{array}$ & & .753 & & \\
\hline $\begin{array}{l}\text { Saya sentiasa bersedia untuk memahami arahan-arahan yang diberikan oleh pihak } \\
\text { majikan }\end{array}$ & & .798 & & \\
\hline $\begin{array}{l}\text { Saya sentiasa bersedia untuk mematuhi arahan-arahan yang diberikan oleh pihak } \\
\text { majikan }\end{array}$ & & .862 & & \\
\hline $\begin{array}{l}\text { Tempat kerja yang kondusif dan selesa membuatkan saya lebih semangat unutk } \\
\text { bekerja. }\end{array}$ & & .457 & & \\
\hline KOTM & 4 & & & \\
\hline Saya menerima banyak imbuhan/bonus daripada syarikat. & & & & .500 \\
\hline $\begin{array}{l}\text { Saya akan menerima bayaran yang lebih sekiranya saya bekerja di luar waktu } \\
\text { bekerja }\end{array}$ & & & & .856 \\
\hline Saya akan menerima elaun sekiranya saya melakukan kerja di luar syarikat. & & & & .890 \\
\hline $\begin{array}{l}\text { Saya diberi peluang untuk memperoleh kenaikan pangkat dan gaji sekiranya saya } \\
\text { berkhidmat untuk jangka masa yang tertentu. }\end{array}$ & & & & .402 \\
\hline
\end{tabular}

JADUAL 3. Analisis kesahan dan kebolehpercayaan instrumen

\begin{tabular}{cccccc}
\hline Konstruk & KMO & Ujian Sferasiti Bartlet & Nilai Eigen & Penerangan Varian & Alfa Cronbach \\
\hline TGJN & 0.763 & $\begin{array}{l}222.694 \\
\mathrm{p}=0.000\end{array}$ & 2.766 & 69.146 & 0.843 \\
PGLN & 0.927 & $\begin{array}{l}842.947 \\
\mathrm{p}=0.000\end{array}$ & 6.421 & 71.343 & 0.947 \\
& & $\begin{array}{l}168.782 \\
\mathrm{p}=0.000\end{array}$ & 2.633 & 65.834 & 0.826 \\
\hline
\end{tabular}

mengesahkan bahawa keupayaan pihak pengurusan menentukan tahap ganjaran setimpal dengan sumbangan pekerja dapat meningkatkan penglibatan mereka dalam organisasi.

\section{DAPATAN PENGUJIAN H3}

Jadual 7 menunjukkan bahawa kemasukan TGJN dan PGLN ke Langkah 2 telah menerangkan perubahan varian dalam KOTM sebanyak 43 peratus. Nilai $\mathrm{R}^{2}$ ini menerangkan
JADUAL 4. Analisis ujian statistik deskriptif dan analisis korelasi Pearson

\begin{tabular}{cccccc}
\hline \multirow{2}{*}{ Konstruk } & \multirow{2}{*}{ Min } & \multirow{2}{*}{$\begin{array}{c}\text { Sisihan } \\
\text { Piawai }\end{array}$} & \multicolumn{3}{c}{ Analisis Korelasi Pearson } \\
\cline { 4 - 5 } & & & 1 & 2 & 3 \\
\hline TGJN & 3.7179 & 0.80779 & 1 & & \\
PGLN & 4.0665 & 0.68042 & $0.548^{* *}$ & 1 & \\
KOTM & 3.4936 & 0.92932 & $0.614^{* *}$ & $0.521^{* *}$ & 1 \\
\hline
\end{tabular}

Nota: Signifikan pada tahap $* * p<0.01$ 
bahawa model kajian ini mempunyai kesan yang besar (Cohen 1988). Manakala, nilai faktor inflasi varian bagi hubungan di antara PGLN dan KOTM ialah 1.000, iaitu lebih kecil daripada 10.0. Ini menunjukkan bahawa PGLN adalah bebas daripada masalah kolineariti (Hair et al. 2006). Seterusnya, keputusan pengujian hipotesis menunjukkan bahawa hubungan antara TGJN, PGLN dan KOTM adalah signifikan $(\beta=.404, p=.000)$. Oleh itu, H3 disokong. Dapatan ini mengesahkan bahawa hubungan di antara tahap ganjaran dan komitmen organisasi adalah dipengaruhi secara tidak langsung oleh penglibatan pekerja.

JADUAL 5. Perhubungan di antara tahap ganjaran dan komitmen organisasi

\begin{tabular}{lc}
\hline $\begin{array}{l}\text { Pemboleh ubah Tidak } \\
\text { Bersandar }\end{array}$ & $\begin{array}{c}\text { Pemboleh Ubah Bersandar } \\
\text { (Komitmen Organisasi) }\end{array}$ \\
\hline Tahap ganjaran & $0.614 * * *$ \\
\hline $\mathrm{R}^{2}$ & 0.377 \\
$\mathrm{R}^{2}$ Terlaras & 0.372 \\
$\mathrm{~F}$ & $69.625 * * *$ \\
\hline
\end{tabular}

Nota: signifikan pada tahap $* * * p \leq 0.001$

JADUAL 6. Perhubungan di antara tahap ganjaran dan penglibatan pekerja

\begin{tabular}{lc}
\hline $\begin{array}{l}\text { Pemboleh ubah Tidak } \\
\text { Bersandar }\end{array}$ & $\begin{array}{c}\text { Pemboleh Ubah Bersandar } \\
\text { (Penglibatan Pekerja) }\end{array}$ \\
\hline Tahap ganjaran & $0.548^{* * *}$ \\
\hline $\mathrm{R}^{2}$ & 0.300 \\
$\mathrm{R}^{2}$ Terlaras & 0.294 \\
$\mathrm{~F}$ & $49.263^{* * *}$ \\
\hline
\end{tabular}

Nota: signifikan pada tahap $* * * p \leq 0.001$

JADUAL 7. Hubungan di antara tahap ganjaran, penglibatan pekerja dan komitmen organisasi

\begin{tabular}{|c|c|c|}
\hline \multirow[t]{2}{*}{ Pemboleh Ubah } & \multicolumn{2}{|c|}{$\begin{array}{l}\text { Pemboleh Ubah Tidak Bersandar } \\
\text { (Komitmen Organisasi) }\end{array}$} \\
\hline & Langkah 1 & Langkah 2 \\
\hline$\frac{\frac{\text { Pemboleh Ubah }}{\text { Tidak Bersandar }}}{\text { Tahap ganjaran }}$ & $0.614 * * *$ & $0.470 * * *$ \\
\hline$\frac{\text { Pemboleh Ubah }}{\text { Pengantara }}$ & & $0.264 * *$ \\
\hline $\mathrm{R}^{2}$ & 0.377 & 0.426 \\
\hline $\mathrm{R}^{2}$ Terlaras & 0.372 & 0.416 \\
\hline $\mathrm{F}$ & $69.625 * * *$ & $42.277 * * *$ \\
\hline$\Delta \mathrm{R}^{2}$ & 0.377 & 0.049 \\
\hline $\mathrm{F} \Delta \mathrm{R}^{2}$ & $69.625 * *$ & $9.676^{* *}$ \\
\hline
\end{tabular}

Nota: Signifikan pada $* * p<0.01 ; * * * p \leq 0.001$
Dapatan kajian ini membuktikan bahawa penglibatan pekerja berupaya bertindak sebagai pemboleh ubah perantara yang penting dalam hubungan di antara tahap ganjaran dan komitmen organisasi. Dalam konteks organisasi kajian, pihak pengurusan mengamalkan penentuan tahap ganjaran berdasarkan pekerjaan (seperti jawatan, lama berkhidmat dan kekananan) dan prestasi (seperti merit) dalam mengurus sistem ganjaran organisasi. Kaedah penentuan tahap ganjaran ini dibuat berdasarkan polisi dan prosedur yang ditetapkan oleh Jabatan Perkhidmatan Awam Malaysia bagi meningkatkan keadilan dan mendorong pekerja menyokong matlamat dan strategi organisasi. Seperti yang diterangkan dalam Jadual 4, kebanyakan responden berpendapat bahawa tahap ganjaran, penglibatan pekerja, dan komitmen organisasi adalah tinggi. Keadaan ini menerangkan bahawa kesediaan pihak pengurusan menentukan tahap ganjaran yang setimpal dengan sumbangan pekerja dapat meningkatkan penglibatan pekerja. Seterusnya, penglibatan ini boleh pula mendorong pekerja meningkatkan komitmen organisasi.

Dapatan kajian ini mengenengahkan tiga implikasi penting, iaitu sumbangan kepada teori, sumbangan kepada pemantapan kaedah penyelidikan, dan sumbangan kepada pengamal. Dari segi sumbangan kepada teori, dapatan kajian ini mengesahkan bahawa penglibatan pekerja bertindak sebagai pemboleh ubah pengantara yang penting dalam hubungan antara tahap ganjaran dengan komitmen organisasi. Penemuan kajian ini adalah selari dengan idea utama yang dikemukakan oleh Teori Penglibatan Kerja (Maslach \& Leiter 1997), Teori Penglibatan Kerja (Schaufeli et al. 2002) dan Model Tuntutan Kerja-Sumber (Bakker 2011; Bakker \& Demerouti 2008), yang mendedahkan bahawa tahap ganjaran adalah satu pengiktirafan yang sangat penting terhadap sumbangan dan pengorbanan pekerja. Sekiranya pihak pengurusan menentukan tahap ganjaran setimpal dengan sumbangan pekerja (seperti kerja atau/dan prestasi) ini akan dapat mendorong pekerja untuk meningkatkan penglibatan yang aktif dalam operasi kerja harian (seperti autonomi dan sokongan yang diberikan oleh penyelia, serta budaya organisasi berprestasi tinggi akan dapat mendorong pekerja untuk mempamerkan daya kreatif, dedikasi, kepuasan dan konsentrasi dalam mencapai sasaran kerja yang ditetapkan). Seterusnya, penglibatan ini boleh pula meningkatkan tahap komitmen pekerja terhadap organisasi (seperti rasa bangga, bertanggungjawab dan terhutang budi dengan organisasi). Dapatan kajian ini juga telah menyokong dan menyebarluaskan kajian-kajian yang dilakukan oleh Rai et al. (2019), dan Aboramadan et al. (2020).

Merujuk kepada pemantapan kaedah penyelidikan, data borang soal selidik kajian ini telah mencapai piawai kesahan dan kebolehpercayaan yang ditetapkan. Oleh itu, tahap pencapaian ini boleh menghasilkan dapatan yang tepat dan boleh dipercayai. Seterusnya, sumbangan terhadap pengamal, dapatan kajian ini boleh digunakan sebagai panduan oleh pengamal untuk menambah baik sistem pengurusan ganjaran. Untuk mencapai tujuan ini, pihak pengurusan perlu memberi perhatian kepada aspek 
berikut: Pertama, jenis, tahap atau/dan amaun ganjaran perlu ditingkatkan selari dengan tuntutan kerja semasa, prestasi pekerja dan kos hidup semasa. Usaha penambahbaikan ini dapat membantu pekerja memenuhi keperluan asas, merasa kepuasan kerja dan memberi konsentrasi untuk menjayakan indikator prestasi organisasi.

Kedua, penentuan tahap ganjaran amat berkait rapat dengan sistem penilaian prestasi. Oleh itu, sistem penilaian prestasi yang kreatif, seperti sistem penilaian prestasi tahunan berorientasi 360 darjah perlu diperkenalkan supaya pihak-pihak yang berkepentingan seperti pandangan rakan sejawatan, pelanggan dan penilaian kendiri diambil kira untuk memastikan ketepatan dan kebolehpercayaan pemarkahan prestasi. Usaha penambahbaikan ini dapat mengurangkan kelemahan dalam mengukur prestasi pekerja, memberi peluang kepada pekerja yang kompeten untuk meningkatkan pendapatan dan kenaikan pangkat, serta mengurangkan sikap prejudis pekerja terhadap sistem pengurusan ganjaran. Ketiga, kandungan dan kaedah latihan pengurusan ganjaran sangat perlu diperbaharui mengikut keperluan semasa kerana ia dapat membantu pengurus dan pekerja untuk dapat memahami kandungan dan kaedah pembahagian ganjaran berdasarkan garis panduan organisasi, serta dapat menggunakan program ganjaran bagi merancang pembangunan kerjaya dalam organisasi. Keempat, pengambilan pekerja yang mempunyai pengalaman kerja, ijazah sarjana pengurusan yang diiktiraf dan sahsiah yang mulia perlu diberi keutamaan untuk mengisi jawatan-jawatan penting dalam jabatan sumber manusia. Kemasukan pekerja yang mempunyai ciri-ciri yang kompeten ini akan dapat digunakan pula untuk menjadi mentor, jurulatih dan kaunselor bagi membimbing para pengurus muda dan penyelia dalam mengurus hak dan kebajikan pekerja, seperti sistem upah dan gaji pekerja. Akhir sekali, teknologi maklumat dan komunikasi yang canggih perlu digunakan bagi meningkatkan kecekapan dalam mengurus sistem ganjaran. Usaha ini amat penting kerana pekerja dapat memahami, menyemak dan membuat aduan dengan mudah tentang jenis, tahap atau/dan amaun ganjaran yang layak diterima melalui laman web dan juga telefon pintar. Keadaan ini boleh mendorong pekerja untuk meningkatkan kepuasan dan prestasi kerja. Sekiranya cadangan di atas diberi pertimbangan yang sewajarnya, ia dapat mendorong pekerja untuk menyokong matlamat program ganjaran organisasi.

\section{KeSIMPULAN}

Kajian ini telah menilai kerangka konseptual yang dibina berdasarkan kajian literatur yang berkaitan dengan pampasan organisasi. Instrumen kajian ini telah mencapai tahap kesahan dan kebolehpercayaan yang ditetapkan. Dapatan pengujian hipotesis pula mengesahkan bahawa penglibatan pekerja berupaya bertindak sebagai pemboleh ubah pengantara yang penting dalam hubungan di antara tahap ganjaran dan komitmen organisasi. Dapatan kajian ini telah menyokong dan menyebarluaskan kajian lepas yang diterbitkan di negara-negara Barat dan Asia. Oleh itu, kajian terkini perlu mempertimbangkan penglibatan pekerja sebagai dimensi yang penting dalam domain pengurusan ganjaran organisasi. Selanjutnya, kajian ini juga mencadangkan bahawa organisasi perlu menentukan tahap ganjaran yang sepadan dengan sumbangan pekerja kerana ia boleh mengubah gelagat pekerja ke arah yang positif (seperti kepuasan, komitmen, penglibatan, kesetiaan, etika dan tidak ingin berhenti kerja secara sukarela). Gelagat pekerja yang sedemikian pula boleh membantu menjayakan dan mengekalkan matlamat dan strategi organisasi dalam era persaingan global dan ekonomi berasaskan pengetahuan.

KEKANGAN DAN CADANGAN KAJIAN AKAN DATANG

Kajian ini mempunyai beberapa batasan konseptual dan metodologi. Pertama, data kaji selidik diambil sekali sahaja dalam tempoh kajian dan ia hanya dapat menggambarkan persepsi responden secara umum terhadap hubungan antara konstruk kajian. Kedua, kajian ini tidak menilai secara terperinci hubungan antara elemen-elemen khusus bagi pemboleh ubah tidak bersandar, pemboleh ubah pengantara, dan pemboleh ubah bersandar. Ketiga, kajian ini dijalankan di pusat-pusat latihan yang berada di bawah kawalselia kerajaan persekutuan Malaysia di Bandar Baru Bangi, Selangor. Keempat, teknik persampelan rawak tidak dapat dilaksanakan sebaliknya kajian ini menggunakan kaedah persampelan purposif. Namun ujian menunjukkan bahawa tidak ada elemen bias yang ketara dalam sampel kajian ini. Batasan-batasan yang dinyatakan boleh mengurangkan keupayaan untuk mengeneralisasikan dapatan kajian ini kepada konteks organisasi yang lebih luas.

Kajian ini mengemukakan beberapa cadangan untuk memantapkan kajian akan datang. Pertama, beberapa ciriciri peribadi dan perkhidmatan responden yang penting seperti jantina, umur, pendapatan, jawatan dan tempoh berkhidmat perlu diambil kira dalam kajian akan datang supaya dapat memahami persamaan dan perbezaan tanggapan responden terhadap model kajian. Kedua, kajian akan datang perlu menilai keberkesanan penglibatan pekerja sebagai pemboleh ubah pengantara di pusat-pusat latihan milik swasta. Dapatan ini dapat dibandingkan pula dengan hasil kajian di pusat-pusat latihan milik kerajaan bagi menghasilkan dapatan yang lebih baik. Ketiga, saiz sampel yang lebih besar perlu diambil supaya dapat mewakili populasi kajian yang lebih baik. Keempat, elemen khusus tahap ganjaran seperti tahap ganjaran kewangan dan tahap ganjaran bukan kewangan perlu dipertimbangkan kerana ia merupakan topik perbincangan yang hangat dalam kajian literatur tentang pampasan organisasi. Kelima, dimensi-dimensi khusus penglibatan pekerja seperti kegigihan, dedikasi dan keasyikan perlu diberi perhatian utama kerana elemen ini dianggap sebagai pemboleh ubah yang sangat penting dalam hubungan di antara tahap ganjaran dan komitmen organisasi. Akhir sekali, ciri-ciri penting komitmen organisasi seperti afektif, 
normatif dan kalkulatif perlu dianalisis kerana ia dinilai sebagai natijah yang penting daripada hubungan di antara tahap ganjaran dan penglibatan pekerja.

\section{RUJUKAN}

Aboramadan, M., Albashiti, B., Alharazin, H. \& Dahleez, K.A. 2020. Human resources management practices and organizational commitment in higher education. International Journal of Educational Management 34(1): 154-174

Adam, J.S. 1963. Towards an understanding of inequity. The Journal of Abnormal and Social Psychology 67(5): 422.

Agarwal, S. \& Al Qouyatahi, K.M.S. 2018. HRM challenges in the age of globalisation. International Research Journal of Business Studies 10(2): 89-98

Albrecht, S.L. 2010. Handbook of employee engagement: Perspectives, issues, research and practice. Aldershot: Elgar Publishing.

Allen, N.J. \& Meyer J.P. 1990. The Measurement and Antecedents of Affective, Continuance and Normative Commitment to the Organization. Journal of Occupational Psychology 63: 1-18

Allen, N.J. \& Meyer J.P. 1996. Affective, continuance, and normative commitment to the organization: an examination of construct validity. Journal of Vocational Behavior 49(3): 252-276

Asri, M. \& Hamrila, A.L. 2007. Faktor-faktor yang mempengaruhi komitmen pekerja di organisasi awam. Jurnal Kemanusiaan 10: 56-64

Azman, I. \& Mohd Ridwan, A.R. 2017. Performance-Based Reward Administration Enhancing Employees' Feelings of Interactional Justice. Studies in Business and Economics 12(1): 5-18

Bachkirov, A.A. 2018. They made me an offer I couldn't refuse! Organizational commitment in a non-Western context. Evidence-based HRM: A Global Forum for Empirical Scholarship 6(1): 77-93

Bakker, A.B. 2011. An evidence-based model of work engagement. Current Directions in Psychological Science 20(4): 265-269

Bakker, A.B. \& Demerouti, E. 2008. Towards a model of work engagement. Career Development International 13: $209-223$

Brown, D. \& Reilly, P. 2013. Reward and Engagement. Compensation \& Benefits Review 45(3): 145-157

Chew, J. \& Chan, C.C.A. 2008. Human resource practices, organizational commitment and intention to stay. International Journal of Manpower 29(6): 503-522

Cohen, J. 1998. Statistical power analysis for the behavioral sciences. Hillsdale, NJ: Lawrence Earlbaum Associates

Creswell, J.W. 2016. Qualitative Inquiry and Research Design: Choosing among Five Approaches. Lincoln: Sage Publications

Fink, J., Zabawa, B. \& Chopp, S. 2019. Employee perceptions of wellness programs and incentives. American Journal of Health Promotion 34(3): 257-260

Fletcher, L. \& Robinson, D. 2013. Measuring and understanding employee engagement. Dlm. Employee Engagement in Theory and Practice, pnyt. C. Truss, R. Delbridge, K. Alfes, A. Shantz \& E. Soane. 273-290. London, England: Routledge

Ghosh, P., Rai, A., Chauhan, R., Baranwal, G. \& Srivastava D. 2016. Rewards and recognition to engage private bank employees: Exploring the "obligation dimension". Management Research Review 39(12): 1738-1751

Gills, B.K. 2010. The return of crisis in the era of globalisation: One crisis or many? Globalisation 7(1-2): 3-8

Haar, J.M. \& Spell, C.S. 2009. How does distributive justice affect work attitudes? The moderating effects of autonomy. The International Journal of Human Resource Management 20(8): 1827-1842

Hair, J.F., Anderson, R.E., Tatham, R.L. \& Black, W.C. 2006. Multivariate Data Analysis. New Jersey: Prentice Hall International

Holdener M., Gut A. \& Angerer A. 2020. Applicability of the User Engagement Scale to Mobile Health: A Survey-Based Quantitative Study. JMIR Mhealth Uhealth 8(1): e13244.

Hoole, C. \& Hotz, G. 2016. The impact of a total reward system of work engagement. SA Journal of Industrial Psychology 42(1): $1-14$

Hulkko-Nyman, K., Sarti, D., Hakonen, A. \& Sweins, C. 2014. Total rewards perceptions and work engagement in elder-care organizations: findings from Finland and Italy. International Studies of Management \& Organization 42(1): 24-49

Jabatan Perkhidmatan Awam Malaysia. 2019. PP Bil.04/2002 Pelaksanaan Sistem Saraan Malaysia Bagi Anggota Perkhidmatan Awam Persekutuan. Ditarik pd 11 April 2020 drpd http://docs.jpa.gov.my/docs/pp/2002/ pp042002.pdf

Judge, T.A., Piccolo, R.F., Podsakoff, N.P., Shaw, J.C. \& Rich, B.L. 2010. The relationship between pay and job satisfaction: A meta-analysis of the literature. Journal of Vocational Behavior 77: 157-167

Kahn, W.A. 1992. To be fully there: Psychological presence at work. Human Relations 45(4): 321-349

Khattak, M.A., Sindhu, M.I., Haider, A. \& Urooj, S.F. 2017. Impact of procedural justice on organizational commitment with moderating effect of pay satisfaction. Jinnah Business Review 5(2): 54-60

Korir, I. \& Kipkebut, D. 2016. The Effect of Reward Management on Employees Commitment in the Universities in Nakuru County-Kenya. Journal of Human Resource Management 4(4): 37-48.

Lawler, E.E. 1971. Pay and organizational effectiveness: A psychological viewpoint. New York: McGraw-Hill

Lawler, E.E. 1981. Pay and organization development. Reading, Massachusetts: Wesley

Leiter, M.P. \& Maslach, C. 2001. Burnout and quality in a spedup world. The Journal for Quality and Participation 24(2): 48-51

Maden, C. 2015. Linking high involvement human resource practices to employee proactivity: the role of work engagement and learning goal orientation. Personnel Review 44(5): 720-738

Martocchio, J.J. \& Martocchio, J. 2019. Human Resource Management. Pearson

Maslach, C. \& Leiter, M.P. 1997. The truth about burnout. San Francisco: Jossey Bass.

Maslach, C., Schaufeli, W. \& Leiter, M. 2001. Job burnout. Annual Review of Psychology 52: 397-422

Mowday, R.T., Steers, R.M. \& Porter, L.W. 1979. The measurement of organizational commitment. Journal of Vocational Behavior 14(2): 224-247

Muhamad Ariff, I., Wan Shahrazad, W.S., Noor Izzaty, I., Mohd Ahsani, A.M. \& Abdul Malek, A.B. 2018. Pengaruh keadilan organisasi, kepuasan kerja, komitmen organisasi dan prestasi tugas terhadap tingkah laku kewargaan 
organisasi dalam kalangan pensyarah. Jurnal Psikologi Malaysia 32(4):75-87.

Mukaihata, T., Fujimoto, H. \& Greiner, C. 2020. Factors influencing work engagement among psychiatric nurses in Japan. Journal of Nursing Management 28(2): 306-316

Newman, J., Gerhart, B. \& Milkovich, G. 2019. Compensation. New York: McGraw-Hill International Edition

Nunally, J.C. \& Bernstein. I.H. 1994. Psychometric theory. New York: McGraw Hill

Othman, R.B., Rapi, R.B.M., Alias, N.E.B., Jahya, A.B. \& Loon, K.W. 2019. Factors Affecting Employee Engagement: A Study among Employees in the Malaysian Construction Industry. International Journal of Academic Research in Business and Social Sciences 9(7): 784-797

Padsakoff, P.M., Mackenzie, S.B., Lee, J.Y. \& Podsakoff, N.P. 2003. Common method biases in behavioral research. A critical review of the literature and recommended remedies. Journal of Applied Psychology 88(5): 879-903

Portal Rasmi Jabatan Perkhidmatan Awam Malaysia. 2020. Skim Perkhidmatan \& Perjawatan. Ditarik pd 11 April 2020 drpd https://www.jpa.gov.my/soalan-lazim-smmerah/skim-perkhidmatan-perjawatan

Rai, A., Ghosh, P. \& Dutta, T. 2019. Total rewards to enhance employees' intention to stay: does perception of justice play any role? Evidence-based HRM: A Global Forum for Empirical Scholarship 7(3): 263-280

Rehman, S., Shareef, A., Mahmood, A. \& Ishaque, A. 2012. Perceived leadership styles and organizational commitment. Interdisciplinary Journal of Contemporary Research in Business 4(1): 616-626

Remo, N. 2012. Comparing Two Models of Employee Engagement: An Examination of Antecedents and Outcome Variables. Disertasi $\mathrm{PhD}$ tak diterbitkan, University of Windsor, Windsor, Ontario, Canada.

Rizescu, A. \& Tileaga, C. 2017. The effects of globalization on the trabsformation of organizational management. Journal of Defense Resources Management 8(1): 135-140

Rothbard, N.P. 2001. Enriching or depleting? The dynamics of engagement in work and family. Administrative Science Quarterly 45(4): 655-684

Salwa, S., Shafiqa, R., Azman, I. \& Ishak, Y. 2015. Peranan sistem ganjaran berdasarkan prestasi dalam meningkatkan komitmen organisasi: Kajian kes penjawat awam di Putrajaya dan Selangor, Malaysia. Geografia-Malaysian Journal of Society and Space 11(10): 51-62

Schaufeli, W.B., Salanova, M., Gonzalez-Roma, V. \& Bakker, A.B. 2002. The measurement of engagement and burnout:
A two sample confirmatory factor analytic approach. Journal of Happiness Studies 3(1): 71-92

Schaufeli, W.B. \& Bakker, A.B. 2003. Test manual for the Utrecht Work Engagement Scale. Manuskrip tak diterbitkan. Utrecht University, Netherlands

Schaufeli, W.B., Bakker, A.B. \& Salonova, M. 2006. The measurement of work engagement with a short questionnaire: A cross-national study. Educational and Psychological Measurement 66(4): 701-716

Scott, D., McMullen, T., \& Stark, M. 2011. The Impact of Rewards Programs on Employee Engagement. Ditarik pd 11 April 2020 drpd https://www.worldatwork.org/docs/ research-and-surveys/survey-brief-the-impact-of-rewardsprograms-on-employee-engagement.pdf

Scrima, F., Lorito, L., Parry, E. \& Falgares, G. 2014. The mediating role of work engagement on the relationship between job involvement and affective commitment. The International Journal of Human Resource Management 25(15): 2159-2173

Unit Pemodenan Tadbiran dan Perancangan Pengurusan Malaysia, 2018. Pekeliling Kemajuan Pentadbiran Awam Bil. 4 Tahun 2018. Ditarik pd 11 April 2020 drpd https:// www.parlimen.gov.my/images/webuser/pengumuman/ PKPA\%20BIL.4_2018-myportfolio\%20Panduan $\% 20$ Kerja\%20Sektor\%20Awam-JD-JOB\%20DESCRIPTION.

Vroom, V.H. 1964. Work and motivation. New York: Wiley

Yao, Y.H.A., Locke, E.A. \& Jamal, M. 2017. On a combined theory of pay level satisfaction. Journal of Organizational Behavior 39(4): 448-461

Nur Syafiqah Abdul Samad

Fakulti Ekonomi dan Pengurusan

Universiti Kebangsaan Malaysia

Emel: nsyafiqahsamad297@gmail.com

Azman Ismail*

Fakulti Ekonomi dan Pengurusan

Universiti Kebangsaan Malaysia

Emel: azisma08@gmail.com

Khairul Azman Aziz

Fakulti Ekonomi dan Pengurusan

Universiti Kebangsaan Malaysia

Emel: khairul.aziz@ukm.edu.my

* Penulis corresponding 